\title{
Prevalence of Methicillin and Vancomycin resistant Staphylococcus aureus on the touch screen of automated teller machines in Dhaka city
}

\author{
Mrityunjoy Acharjee', Takia Akter ${ }^{1}$, Nafisa Tabassum², M. Majibur Rahaman ${ }^{3}$ and Rashed Noor ${ }^{2}$ * \\ ${ }^{1}$ Department of Microbiology, Stamford University Bangladesh, Dhaka-1217; ${ }^{2}$ School of Life Sciences (SLS), Independent University, Bangladesh (IUB), Dhaka \\ 1229, Bangladesh; ${ }^{3}$ Department of Microbiology, University of Dhaka, Dhaka-1100
}

\begin{abstract}
The present study was undertaken to observe the transmission of microbial contaminants through different electronic devices. Five different bacteria such as Escherichia coli, Staphylococcus aureus, Staphylococcus epidermidis, Pseudomonas spp. and Bacillus spp. were cultivated from the surface of 50 different automated teller machines (ATMs) of 10 different banks located in Dhaka City. Among them, the number of Pseudomonas spp. and S. epidermidis were found up to $10^{4} \mathrm{cfu} / \mathrm{ml}$ while the $S$. aureus was quantified up to $10^{6} \mathrm{cfu} / \mathrm{ml}$. Fungal contamination was also observed in all cases within the range of $10^{4}$ and $10^{5} \mathrm{cfu} / \mathrm{ml}$. Most of the isolates were found to be resistant against more than one antibiotic. Only Streptomycin and Gentamicin were found to be effective against all the bacteria. Out of 50 strains (coagulase positive) of $S$. aureus, $40(80 \%)$ were found as Oxacillin and Methicillin resistant. Among 40 MRSA strains, 25 (62.5\%) were found to be resistant against vancomycin which is referred to as VRSA. The isolated MDR bacteria from the surface of the ATM may be a health concern for the users.
\end{abstract}

Keywords: Multi drug resistance, Automated teller machine, Antibiotic, VRSA, MDR.

\section{Introduction}

In today's world, the emerging infectious diseases are the major threat to human health and cause serious fatal outcome in both local and global perspective ${ }^{1,2}$. The proliferation of pathogenic microorganisms including bacteria, virus, fungi and parasites into the human body through contaminated hand, food, water and dust particles may cause diseases like diarrhea and dysentery ${ }^{3-5}$. The use of electronic device such as taps, ATM machine, computer, telephones etc. are increasingly being used to reduce the work load and time ${ }^{6,7}$. In public health point of view the surface of these devices may act as one of the major and common routes of pathogenic microbes by which they can easily spread ${ }^{8,9}$. Several studies have already been conducted throughout the world on the presence of pathogenic contamination on the touch screen of electronic devices like ATM booth, public telephone booths, keypad of mobile phones and computers ${ }^{3,9}$. As described in early studies the mobile phones, computer keyboards and automated teller machines (ATM) are now becoming the source of infection because of the vast dermal contact with the key panel ${ }^{10-13}$. Previous study suggested that most noteworthy pathogens such as Staphylococcus epidermidis, Staphylococcus aureus (MRSA), Staphylococcus alpha haemolyticus, Enterococcus faecalis, Bacillus subtilis, coliforms, Pseudomonas aeruginosa, Escherichia coli and Acinetobacter calcoaceticus have been found from the surface of different electronic devices ${ }^{14}$. The probability of dissemination of such microbial contaminates is very high in densely populated country like Bangladesh where the major community doesn't maintain the personal hygiene and sanitation procedure ${ }^{8}$. Therefore, increased use of Automated Electronic devices by the people who are not aware of the sanitation and hygiene may pose potential threat to public health. 15-19. Considering all the facts, this study attempted to find out the frequency of multidrug resistant strains (MDR) as well as methicillin resistant Staphylococcus aureus (MRSA) and vancomycin resistant Staphylococcus aureus (VRSA) on the touch screen of automated teller machines (ATMs) of different banks.

\section{Materials And Methods}

The samples were collected from 50 ATM booths of 10 different banks ( 5 ATM booths of each bank e.g $5 \times 10=50$ ) such as Dutch Bangla Bank, City bank, Standard Chartard bank, BRAC Bank, estern Bank, AB Bank, Islamic Bank, Marchentile Bank, HSBC and First Security Bank in Dhaka city, Bangladesh, from June 2017 to September 2017. The samples were collected from the surface of the keypad and touch screen of ATMs through sterile cotton swabs ${ }^{20}$. The sample containing swabs were then immediately inoculated into test tubes containing nutrient broth as enrichment media and transferred in to the laboratory by following thermostatic condition. Within $1 \mathrm{hr}$ the samples were processed for microbiological analysis according to the standard guideline ${ }^{21}$.

The $0.1 \mathrm{ml}$ of each sample from the dilution $10^{-3}$ was introduced on to the nutrient agar and Sabouraud dextrose agar for the isolation of total viable bacteria and fungi, respectively. Subsequently, MacConkey agar, Manitol Salt agar, Cetrimide agar

*Corresponding author:

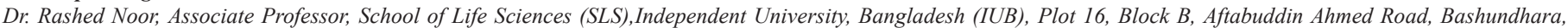
Dhaka 1229,Bangladesh. E-mail: noorrashed@yahoo.com 
and Starch agar (Manufactured by Hi-media Laboratories Pvt. Ltd., Mumbai) were used as selective media for the quantification of coliforms (E. coli), Staphylococcus spp., Pseudomonas spp., and Bacillus spp., consecutively ${ }^{21.22}$.All the inoculated plates were incubated at $37^{\circ} \mathrm{C}$ for 24 hours except SDA plates, which were incubated at $25^{\circ} \mathrm{C}$ for 48 hours. For the confirmation of $E$. coli the lactose fermenting pink colonies from the MacConkey agar were further introduced on to the EMB media (Manufactured by Hi-media Laboratories Pvt. Ltd., Mumbai) to observe the green metallic sheen.

The colony characteristics of the isolates (size, shape, arrangement and color along with their gram reaction) on different selective media were presumptively examined according to the standard microbiological laboratory manual written by James G. Cappuccino ${ }^{21}$. Finally, the standard biochemical tests were performed (triple sugar iron test, citrate test, IMVIC test, MIU test, catalase test, nitrate, urease, gelatine, starch and oxidase) for the identification of all the pathogens (Table 2). Coagulase test was performed for S. aureus, $10 \mu \mathrm{l}$ of the antiserum was taken on the slide with the suspension of the organism. Finally, agglutination was observed against light and the results were recorded $21,23,19$.

According to the guidelines provided by the Clinical Laboratory Standard Institute (CLSI), the antibiotic susceptibility pattern of the isolates was examined using disc diffusion method ${ }^{24,25}$. The overnight inoculums of the isolates (Escherichia coli, Pseudomonas spp., Staphylococcus aureus, Staphylococcus epidermedis and Bacillus spp.) were adjusted to the turbidity of 0.5 McFarland standards $\left(10^{8} \mathrm{CFU} / \mathrm{mL}\right)$ and swabbed onto Mueller-Hinton agar (MHA) Manufractured by (Hi-media Laboratories Pvt. Ltd., Mumbai) ${ }^{20}$. The antibiotic disc used in the study included polymixin B (300 unit), streptomycin (10 $\mu \mathrm{g})$, gentamycine $(10 \mu \mathrm{g})$, nalidixic acid $(30 \mu \mathrm{g})$, azythromycine (15 $\mu \mathrm{g})$, penicillin $\mathrm{G}(10 \mu \mathrm{g})$, erythromycin $(15 \mu \mathrm{g})$, amoixicilln (30 $\mu \mathrm{g})$, ceftriaxone $(30 \mu \mathrm{g})$, ciprofloxacin $(5 \mu \mathrm{g})$, ampicillin $(10$ $\mu \mathrm{g})$, chloramphenicol $(30 \mu \mathrm{g})$ and cefixime $(5 \mu \mathrm{g})$. All the plates were incubated at $37{ }^{\circ} \mathrm{C}$ for $12-18$ hours and examined for formation of the zone of inhibitions ( $\mathrm{mm}$ ).

For the detection of MRSA and VRSA, overnight incubated suspension of Staphylococcus aureus (cell turbidity was adjusted to $0.5 \mathrm{McF}$ arland standards) were introduced on to the Mueller Hinton Agar (MHA) and the antibiotic discs (methicillin $5 \mathrm{mg}$ and vancomycine $30 \mathrm{mg}$ ) were placed onto the plates at spatial distance of $5 \mathrm{~mm}$ to observe the range of zone diameter for the detection of strain as MRSA and VRSA ${ }^{19}$. A blank disc was introduced as a negative control. All plates were incubated for $24 \mathrm{~h}$ at $37{ }^{\circ} \mathrm{C}$ to observe the oxacillin \& methicillin and vancomycin resistant $S$. aureus.

\section{Results and Discussion}

The dissemination rate of diseases causing bacteria is very high in densely populated countries where sanitation and hygiene condition are poor ${ }^{12,13,20}$.
Existence of microbial contamination on the touches screen of ATMs

Total five isolates such as E. coli, Staphylococcus aureus, Staphylococcus epidermidis, Pseudomonas spp. and Bacillus spp. were presumptively identified from the 50 ATM booths of 10 different banks (5 ATM booths were selected for each different bank) (Table 1). Staphylococcus aureus, Staphylococcus epidermidis, Pseudomonas spp. were found in the surface of all Automated teller machine of 50 ATM booths while the existence of E. coli was found in the device of 30 ATM booths out of 50 and Bacillus spp. was present in 20 ATM booths. Adjacent to the bacterial load all the surface of ATMs exhibited the overall fungal contamination those were not further identified specifically (Table 1).

Among the five isolates Pseudomonas spp., Staphylococcus aureus and Staphylococcus epidermidis were found in high number than E. coli and Bacillus spp. The colonization rate of Staphylococcus aureus was observed up to $10^{6} \mathrm{cfu} / \mathrm{ml}$ while Staphylococcus epidermidis was found up to $10^{4} \mathrm{cfu} / \mathrm{ml}$. For the both species of Staphylococcus the maximum load was observed on the ATMs pad of Dutch Bangla Bank, Standard Chartard bank and estern Bank. Among the ten Bank, E. coli was present in 6 ATMs up to $10^{4} \mathrm{cfu} / \mathrm{ml}$ except BRAC Bank, estern Bank, AB Bank, Islamic Bank, while Bacillus spp. was found on the device of ATMs of Dutch Bangla Bank, City bank, Islamic Bank, Marchentile Bank up to $10^{3} \mathrm{cfu} / \mathrm{ml}$. Pseudomonas spp. was found in all the ATMs up to $10^{4} \mathrm{cfu} / \mathrm{ml}$ (Table 1). The morphological characteristics of isolates were observed through microcopy and different biochemical test (Tables $2 \& 3$ ). Previously it was reported that skin diseases and hospital acquired infection can be transmitted from infected person to the healthy host through unclean touch screen of electronic devices ${ }^{26,27}$. Another research group reported that mouse of computer and the key pad of mobile phone can serve as potential vector for transmission of infectious pathogens like Acinetobacter spp., S. aureus as well as extended-spectrum ${ }^{2}$ lactamase ESBL-positive Enterobacteriaceae 28-33,7,13.

\section{Antibiotic susceptibility pattern of the isolates}

Present study tried to unveil the efficacy of the 12 commonly available drugs against the isolates found from the surface area of the ATMs of different banks. Although some antibiotics used in this study had narrow spectrum of activity against either Gram positive or Gram negative bacteria. Most of the isolates (E. coli, Staphylococcus aureus, Staphylococcus epidermidies and Pseudomonas spp.) were found to be resistant against maximum number of antibiotics. Only Streptomycin $(10 \mu \mathrm{g})$, Nalidixic acid $(30 \mu \mathrm{g})$, Azithromycin $(15 \mu \mathrm{g})$, Erythromycine $(15 \mu \mathrm{g})$, Gentamicin $(10 \mu \mathrm{g})$, Amoxicillin $(30 \mu \mathrm{g})$, Ceftriaxone $(30 \mu \mathrm{g})$ and Ciprofloxacin $(5 \mu \mathrm{g})$ were found highly effective against Bacillus spp. (Table 3). Streptomycin $(10 \mu \mathrm{g})$ and Gentamicin $(10 \mu \mathrm{g})$ were found to be effective against most of the isolated strain except Staphylococcus aureus (Table 4). 
Drug resistant aspect of Staphylococcus aureus against Methicillin and Vancomycin

Total $50 \mathrm{~S}$. aureus were isolated from the ATM booths, among them, 40 were found to be resistant against methicillin \& oxacillin that indicated $80 \%$ MRSA. Among the $80 \%$ of MRSA, $62.5 \%$ showed resistance against vancomycin as VRSA (Table 5). As described in earlier studies, dissemination of such MRSA \& VRSA strain through the dirty surface of the ATMs devices is the main reason to produce several diseases ${ }^{19,34}$.

From the previous findings and current investigation, it can be concluded that surface area of different electronic devices harbor several bacteria including MDR strain. In most of the findings Staphylococcus spp. were found as foremost bacteria with resistant mechanisms against more than one antibiotic. However, the present study successfully revealed the propagation of MRSA and VRSA on the surface area of ATMs of bank which has generated a new dimension of this study. This finding has massive impact in Bangladesh perspective because there is no sufficient reports have published yet on the MRSA and VRSA identified from the surface of electronic device especially from ATMs booth. Some research groups have been reported previously on the presence of methicillin and vancomycin resistant $S$. aureus isolated from different food and clinical samples ${ }^{35,36}$.

Table 1. Detection of microrganisms on the surface of ATMs (cfu/ml).

\begin{tabular}{lcccccc}
\hline Name ofSamples & Fungi & E. coli & $\begin{array}{c}\text { Pseudomonas } \\
\text { spp. }\end{array}$ & $\begin{array}{c}\text { Staphylococcus } \\
\text { aureus. }\end{array}$ & $\begin{array}{c}\text { Staphylococcus } \\
\text { epidermidis. }\end{array}$ & $\begin{array}{c}\text { Bacillus } \\
\text { spp. }\end{array}$ \\
\hline Duch Bangla Bank (n=5) & $2.0 \times 10^{5}$ & $2.0 \times 10^{3}$ & $3.8 \times 10^{3}$ & $2.8 \times 10^{6}$ & $2.8 \times 10^{4}$ & $2.3 \times 10^{2}$ \\
City bank (n=5) & $4.0 \times 10^{5}$ & $2.7 \times 10^{3}$ & $1.0 \times 10^{3}$ & $4.3 \times 10^{3}$ & $1.7 \times 10^{3}$ & $1.9 \times 10^{3}$ \\
Standard Chartard bank (n=5) & $7.5 \times 10^{5}$ & $4.7 \times 10^{4}$ & $5.5 \times 10^{3}$ & $7.0 \times 10^{5}$ & $4.5 \times 10^{4}$ & 0 \\
BRAC Bank (n=5) & $2.5 \times 10^{4}$ & 0 & $1.8 \times 10^{4}$ & $2.9 \times 10^{3}$ & $1.1 \times 10^{3}$ & 0 \\
Estern Bank (n=5) & $4.5 \times 10^{5}$ & 0 & $4.5 \times 10^{3}$ & $4.7 \times 10^{3}$ & $4.7 \times 10^{4}$ & 0 \\
AB Bank (n=5) & $3.5 \times 10^{5}$ & 0 & $3.7 \times 10^{4}$ & $3.5 \times 10^{3}$ & $5.7 \times 10^{3}$ & 0 \\
Islamic Bank (n=5) & $2.0 \times 10^{4}$ & 0 & $2.0 \times 10^{3}$ & $2.8 \times 10^{3}$ & $2.0 \times 10^{3}$ & $3.0 \times 10^{2}$ \\
Marchentile Bank (n=5) & $1.5 \times 10^{5}$ & $4.0 \times 10^{3}$ & $4.5 \times 10^{3}$ & $1.5 \times 10^{3}$ & $4.4 \times 10^{3}$ & $2.7 \times 10^{2}$ \\
HSBC (n=5) & $4.5 \times 10^{4}$ & $7.0 \times 10^{3}$ & $6.7 \times 10^{4}$ & $4.0 \times 10^{3}$ & $6.0 \times 10^{3}$ & 0 \\
First security Bank (n=5) & $2.0 \times 10^{5}$ & $2.0 \times 10^{3}$ & $4.7 \times 10^{3}$ & $2.8 \times 10^{3}$ & $2.7 \times 10^{3}$ & 0 \\
\hline
\end{tabular}

All the experiments were performed in triplicates and the results were reproducible.

Microbial load were enumerated from 50 ATM booth ( 5 booth under 10 bank) and Average microbial load from each bank has been given in the table

Table 2. Biochemical identification of the microorganisms

\begin{tabular}{|c|c|c|c|c|c|c|c|c|c|c|c|c|c|c|c|c|c|}
\hline \multirow{2}{*}{ Microorganisms } & \multicolumn{3}{|c|}{ TSI } & \multirow{2}{*}{ 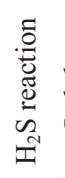 } & \multirow{2}{*}{$\frac{0}{\frac{0}{0}}$} & \multirow{2}{*}{$\stackrel{\mathscr{L}}{\Sigma}$} & \multirow{2}{*}{$s$} & \multirow{2}{*}{ 苛 } & \multirow{2}{*}{ 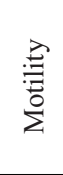 } & \multirow{2}{*}{ 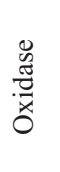 } & \multirow{2}{*}{ 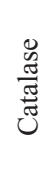 } & \multirow{2}{*}{ 莺 } & \multirow{2}{*}{ 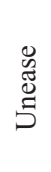 } & \multirow{2}{*}{ 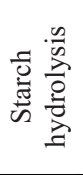 } & \multirow{2}{*}{ 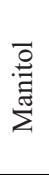 } & \multirow{2}{*}{ 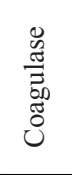 } & \multirow{2}{*}{ 怘: 芯 } \\
\hline & $\frac{\vec{*}}{\tilde{\omega}}$ & 壭 & $\tilde{0}$ & & & & & & & & & & & & & & \\
\hline E. coli & $\mathrm{Y}$ & $\mathrm{Y}$ & + & - & - & + & - & - & + & - & + & + & - & - & + & ND & - \\
\hline Staphylococcus aureus & $\mathrm{Y}$ & $\mathrm{R}$ & - & - & - & + & + & + & - & - & + & + & + & - & + & + & + \\
\hline $\begin{array}{l}\text { Staphylococcus } \\
\text { epidermidis }\end{array}$ & $\mathrm{Y}$ & $\mathrm{R}$ & + & + & - & - & + & - & - & - & + & + & + & - & - & - & - \\
\hline Bacillus spp. & $\mathrm{Y}$ & $\mathrm{R}$ & - & - & + & + & - & - & $+/-$ & - & + & + & - & + & - & ND & + (rapid) \\
\hline Pseudomonas spp. & $\mathrm{R}$ & $\mathrm{R}$ & - & - & - & - & - & + & + & + & + & + & - & - & + & ND & + (rapid) \\
\hline
\end{tabular}

ND: Not done; TSI: Triple Sugar Iron Test; Y: Yellow (Acid); R: Red (Alkaline); MR: Methyl red; VP: Voges-Proskauer

Table 3. Colony morphology of the isolates

\begin{tabular}{|c|c|c|c|}
\hline Sample no & Microorganisms & Morphological characteristics & Gram staining result \\
\hline 1 & E. coli & Flat, smooth pinkish colonies on MacConkey agar and rod shaped motile organism & Gram-negative \\
\hline 2 & Staphylococcus Aureus & Large, yellow, irregular, endulate, raised, cocci, cluster on Manitol salt agar & Gram-positive \\
\hline 3 & Staphylococcus epidermidis & Large, pink, irregular, endulate, raised, cocci, cluster on Manitol salt agar & Gram-positive \\
\hline 4 & Pseudomonas spp. & White colorless to golden colonies on MacConkey agar and rod shaped organism & Gram-negetive \\
\hline 5 & Bacillus spp. & Moderate, violet, irregular, lobate, raised, rod, chain on Starch agar & Gram-positive \\
\hline
\end{tabular}

All the experiments were performed in triplicates and the results were reproducible 
Table 4. Antibacterial susceptibility test of the isolates

\begin{tabular}{|c|c|c|c|c|c|c|c|c|c|c|c|}
\hline \multirow{3}{*}{ Antibiotic } & \multirow{3}{*}{ 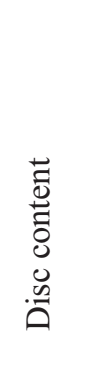 } & \multicolumn{9}{|c|}{ Isolates } & \multirow{3}{*}{$\begin{array}{c}\stackrel{0}{\pi} \\
\stackrel{5}{\mathrm{~S}} \\
(\%)\end{array}$} \\
\hline & & $\begin{array}{l}\widetilde{8} \\
0\end{array}$ & 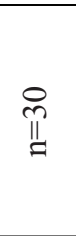 & 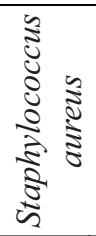 & 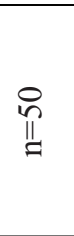 & 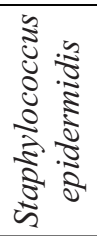 & $\stackrel{\circ}{\stackrel{\Perp}{\|}}$ & 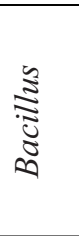 & $\stackrel{\stackrel{ }{\Perp}}{=}$ & 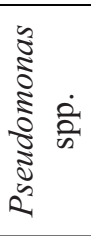 & \\
\hline & & $\begin{array}{c}\mathrm{R} \\
(\%)\end{array}$ & $\begin{array}{c}\mathrm{S} \\
(\%)\end{array}$ & $\begin{array}{c}\mathrm{R} \\
(\%)\end{array}$ & $\begin{array}{c}\mathrm{S} \\
(\%)\end{array}$ & $\begin{array}{c}\mathrm{R} \\
(\%)\end{array}$ & $\begin{array}{c}\mathrm{S} \\
(\%)\end{array}$ & $\begin{array}{c}\mathrm{R} \\
(\%)\end{array}$ & $\begin{array}{c}\mathrm{S} \\
(\%)\end{array}$ & $\begin{array}{c}\mathrm{R} \\
(\%)\end{array}$ & \\
\hline Polymixin B & $\begin{array}{l}300 \\
\text { units }\end{array}$ & 100 & 0 & 100 & 0 & 0 & 100 & 100 & 0 & 0 & 0 \\
\hline Streptomycin & $10 \mu \mathrm{g}$ & 0 & 100 & 100 & 0 & 0 & 100 & 0 & 100 & 0 & 100 \\
\hline Gentamicin & $10 \mu \mathrm{g}$ & 0 & 100 & 100 & 0 & 0 & 100 & 0 & 100 & 0 & 100 \\
\hline Nalidixic acid & $30 \mu \mathrm{g}$ & 100 & 0 & 100 & 0 & 100 & 0 & 0 & 100 & 0 & 100 \\
\hline Azithromycin & $15 \mu \mathrm{g}$ & 100 & 0 & 100 & 0 & 100 & 0 & 0 & 100 & 100 & 0 \\
\hline Erythromycine & $15 \mu \mathrm{g}$ & 100 & 0 & 100 & 0 & 100 & 0 & 0 & 100 & 100 & 0 \\
\hline Amoxicillin & $30 \mu \mathrm{g}$ & 100 & 0 & 100 & 0 & 100 & 0 & 0 & 100 & 100 & 0 \\
\hline Ceftriaxone & $30 \mu \mathrm{g}$ & 100 & 0 & 100 & 0 & 100 & 0 & 0 & 100 & 100 & 0 \\
\hline Ciprofloxacin & $5 \mu \mathrm{g}$ & 100 & 0 & 100 & 0 & 100 & 0 & 0 & 100 & 100 & 0 \\
\hline Ampicillin & $10 \mu \mathrm{g}$ & 100 & 0 & 100 & 0 & 100 & 0 & 100 & 0 & 100 & 0 \\
\hline Chloramphenicol & $30 \mu \mathrm{g}$ & 100 & 0 & 100 & 0 & 100 & 0 & 100 & 0 & 100 & 0 \\
\hline Cefixime & $5 \mu \mathrm{g}$ & 100 & 0 & 100 & 0 & 100 & 0 & 100 & 0 & 100 & 0 \\
\hline
\end{tabular}

All the experiments were performed in triplicates and the results were reproducible

R Resistant

S Sensitive

Table 5. Detection of methicillin and vancomycin resistant Staphylococcus aureus (MRSA \&VRSA)

\begin{tabular}{lccc}
\hline Microorganism & No of isolates & $\begin{array}{c}\text { Resistance against } \\
\text { Oxacillin\& Methicillin }\end{array}$ & $\begin{array}{c}\text { Resistant } \\
\text { presentence (\%) }\end{array}$ \\
\hline Staphylococcus aureus & $\mathrm{n}=50$ & 40 & 80 \\
& Detection of Vancomycine resistant strain among MRSA & \\
Isolate & No of MRSA isolates & Resistance againstVancomycin & Resistant presentence (\%) \\
Staphylococcus aureus $(\mathrm{n}=50)$ & $\mathrm{n}=40$ & 25 & 62.5 \\
\hline
\end{tabular}

All the experiments were performed in triplicates and the results were reproducible

\section{Conclusion}

As a final point, this study unveiled the existence of different microorganisms on the surface of the touches screen of ATMs of different bank. Based on the antibiogram study of the isolates some bacteria were found to be resistant against more than one antibiotics. The most significant findings of this study was the incidence of methicillin and vancomycin resistant $S$. aureus, which is so alarming for the daily users. To minimize the rapid spread of such drug resistant pathogen, the surface of ATM devices should be cleaned regularly by applying proper disinfectant and people should more suspicious regarding their personal cleanliness. However, further molecular study is required to detect the resistant gene to take the necessary action against the bacteria.

\section{Acknowledgement}

We are thankful to Microbiology Laboratory, Stamford University Bangladesh for the technical facilities. 


\section{References}

1. Noor R and Munna MS. 2015. Emerging diseases in Bangladesh: Current microbiological research. Tzu. Chi. Med. J. 27(2): 49-53

2. Cohen ML. 2000. Changing patterns of infectious disease. Nature 406 (6797): 762-7. DOI: $10.1038 / 35021206$

3. Acharjee M, Rahman F, Beauty SA, Feroz F, Rahman MM and Noor R. 2011. Microbiological study on supply water and treated water in Dhaka city. Stamford J. Microbial. 1(1): 42-45.

4. Acharjee M, Jahan F, Rahman F and Noor R. 2014a. Bacterial Proliferation in Municipal Water Supplied in Mirpur Locality of Dhaka City, Bangladesh. Clean - Soil, Air, Water. 42(4): 434-441.

5. Noor et al 2014

6. Barke J, Vipondand IB and Bloomfield SF. 2004. Effects of cleaning and disinfection in reducing the spread of Norovirus contamination via environmental surfaces. J of Hospital Infe. 58(1): 42-9. [Benjamin/ Cummings Publishing Co., Inc., Menlo Park, California].

7. Lopez GU, Gerba CP, Tamimi AH, Kitajima M, Maxwell SL and Roseb JB. 2013. Transfer Efûciency of Bacteria and Viruses from Porous and Nonporous Fomites to Fingers under Different Relative Humidity Conditions. Appl and Env Microbiol. 79(18): 5728-5734.

8. Nester EW, Evans CR, Nancy P, Denise GA and Martha TT. 2004. The genus: Staphylococcus. In: Nester EW, editor. Microbiology - A Human Perspective. 2nd ed. New York: McGraw Hill. 693-5.

9. White LF, Dancer SJ and Robertson CA. 2007. Microbiological evaluation of hospital cleaning methods. Int J Environ Health Res. 17(4): 285-95.

10. Kapdi M, Hoskote SS and SR Joshi. 2008. Health hazards of mobile phones: an Indian perspective. J Assoc Physi Ind. 56: 893-7.

11. Hubar JS and Pelon W. 2005. Low-cost screening for microbial contaminants in aerosols generated in a dental office. Gen Dent. 53(4): 270-2.

12. Nworie O, Mercy M, Chukwudi A, Oko I, Chukwudum SO and Agah VM. 2012. Antibiogram of bacteria isolated from automated teller machines within abakaliki metropolis. Am J Infect Dis. 8(4): 168-74.

13. Tekerkekoglu MS, Yakupogullari Y, Otlu B and Daumen Y. 2013. Bacteria found on bank's automated teller machines (ATMs). Afr. J. Microbiol Res. 7(16): 1619-21.

14. Jerkovic-Mujkic A, Besta R and Memisevic S. 2013. Bacterial contamination of public telephones in the downtown area of Sarajevo. Afr J Microbial Res. 7(17): 1664-7.

15. Velayatiaa M, Farnia P, Tabarsi P, Ghanavi J and Ziazarifi AH. 2009. Emergence of new forms of totally drug-resistant tuberculosis bacilli: super extensively drug-resistant tuberculosis or totally drugresistant strains in Iran. Chest. 136(2): 420-5.

16. Noor R, Uddin MA, Haq MA, Munshi SK, Acharjee M and Rahman MM. 2013. Microbiological study of vendor and packed fruit juices locally available in Dhaka city, Bangladesh. Inter Food Res J. 20(2): 1011-1015.

17. Dutta S, Hassan MR, Rahman F, Jilani MFA and Noor R. 2013. Study of antimicrobial susceptibility of clinically significant microorganisms isolated from selected areas of Dhaka, Bangladesh. Bangladesh. J Med Sci. 12(1): 34-42.

18. Fair RJ and Tor Y. 2014. Antibiotics and Bacterial Resistance in the 21st Century. Perspective in Med Che. 6: 25-64.

19. Hasan R, Acharjee M and Noor R. 2016. Prevalence of Vancomycin Resistant Staphylococcus aureus(VRSA) in Methicillin Resistant $S$. aureus (MRSA) Strains Isolated from Burn Wound Infections. Tzu Chi Med J. 28(2): 49-53
20. Ramesh N, Pillai AP, Rajannambiar M, Prasanth M, Shanthini T, Gothandam KM and Karthikeyan S. 2015. Prevalence of multi drug resistant strains on touch screen of automated teller machine. Asian $J$ PharmClin Res. 8(2): 409-411

21. Cappuccino JG and Sherman N. 1996. Microbiology - A laboratory manual. The Microbiology - A laboratory manual. $4^{\text {th }}$ ed. The Benjamin/ Cummings Publishing Co., Inc., Menlo Park, California.

22. Acharjee M, Ahmed E, Munshi SK and Noor R. 2014b. Validation of $\gamma$ irradiation in controlling microorganisms in fish. Nutri \& Food Sci. 44(3): 258-266

23. Alfrad EB. 2007. Bensons Microbiological Applications. Mcgraw-Hill Book Company, New York

24. CLSI. 2009. Performance standards for antimicrobial susceptibility testing; 19th informational supplement. CLSI M100-S19 Clinical and Laboratory Standards Institute, Wayne, PA

25. Ferraro MJ, Craig WA and Dudley MN. 2001. Performance standards for antimicrobial susceptibility testing. Pennsylvania, USA: NCCLS.

26. Mathai E, Allegranzi B, Kilpatrick C and Pittet D. 2010. Prevention and control of health-care associated infections through improved hand hygiene. Indian J. Med. Microbiol. 28(2): 100-106

27. Bures S, Fishbain JT, Uyehara CFT, Parke JM and Berg BW. 2000. Computer keyboards and faucet handles as reservoirs of nosocomial pathogens in the intensive care unit. Ame J of Infec Con. 28(6): 465-71

28. Dogan M, Feyzioglu B, Ozdemir M and Baysal B. 2008. Investigation of microbial colonization of computer keyboards used inside and outside hospital environments. Mikro biyol Bul. 42(2): 331-6.

29. Abban S and Debrah KT. 2011. Automatic teller machines (ATMs) as potential sources of food borne pathogens - A case study from Ghana. Nat Sci. 9(9): 63-7.

30. Tekerekoglu MS, Duman Y, Serindag A, Cuglan SS, Kaysadu H and Tunc E. 2011. Do mobile phones of patients, companions and visitors carry multidrug-resistant hospital pathogens. Ame J of Infe Con. 39(5): $379-81$.

31. Chukwudi A, Donatus CL and Eucharia CO. 2013. Bacteriological examination of Computer keyboards and mouse devices and their susceptibility patterns to disinfectants. Ame $J$ of Bio and Bioeng. 1(3): 36-43.

32. Onuoha SC and Fatokun K. 2014. Bacterial contamination and public health risk associated with the use of bank's automated teller machines (ATMs) in Ebonyi state, Nigeria. Ame J of Pub Hea. 2(2): 46-50.

33. Nagajothi J, Jeyakumari D, Vigneshwaran S, Kumar PR, Bharatwaj RS and Bagyalakshmi R. 2015. Study of Prevalence of Microbial Contamination with its Antibiotic Resistance Pattern in Automated Teller Machine in and around Puducherry, India. Int. J. Earth. Env. Health. 1(1): 27-31.

34. Chowdhury FFK, Acharjee M and Noor R. 2016. Maintenance of environmental sustainability through microbiological study of pharmaceutical solid wastes. Clean - Soil, Air, Water. 44(3): 309-316.

35. Japoni A, Alborzi AV, Rasouli M and Pourabbas B. 2004. Modified DNA extraction for rapid PCR detection of methicillinresistant Staphylococci. Iranian Bio J. 8(3): 61-5.

36. Mehdinejad M, Frajzade A and Jolodar A. 2008. Study of Methicillin resistance in Staphylococcus aureus and species of coagulase negative Staphylococci isolated from various clinical specimens. Pak. J. Med. Sci. 24(5): 115-7. 